\title{
RECTAL DRUG DELIVERY TO PAEDIATRIC POPULATION
}

\author{
MATEA BULIĆ ${ }^{1}$, CATHERINE TULEU²
}

\begin{abstract}
Despite its unpopularity, the rectal route of paediatric drug administration remains of interest especially in pre-school children as it can overcome some drug delivery challenges with oral and parenteral routes. Few studies have been conducted on the use and acceptability of traditional rectal dosage forms (i.e., suppositories, enemas and gels) in different parts of the world. It showed that barrier to adoption could be linked with poor knowledge, little information and understanding of this administration modality. Reformulation for the rectal delivery of drugs intended for oral and/or parenteral administration that do not reach their full potential, was explored by a study at University College London. The top 3 candidates were Azithromycin, Amodiaquine and Raltegravir. Little rectal delivery innovation has occurred but topics such as acceptability and use of rectal drug delivery; types of rectal dosage forms and reformulation considerations are discussed presently in order to raise awareness around the need to modernise rectal dosage forms this to achieve the full potential for successful reformulation.
\end{abstract}

Keywords: CHILDREN, RECTAL DRUG DELIVERY, RECTAL DOSAGE FORMS, REFORMULATION

\section{Introduction}

Paediatric drug design is very complex and delivering of a medicine to a child is challenging with respect to finding a correct medication applicable to the patient's medical condition, identifying adequate formulations convenient for administration and dosing precision (1). This is due to the significant differences in physiologic, pharmacokinetic, pharmacodynamic and physical capabilities in paediatric population compared to adults. The major variations and changes are recorded in pharmacokinetics of paediatric patients, making it challenging to find the appropriate treatment for a disease (2). Such examples include achlorhydria, decrease in liver volume which reduces drug biotransformation through processes of oxidation, hydrolysis and reduction, etc. $(3,4)$.

${ }^{1}$ Pharmaceutical Product Development,

Cambridge, UK

${ }^{2}$ University College London, School of Pharmacy

\section{Address:}

Matea Bulić, MSc in Pharmaceutics

Pharmaceutical Product Development

11 Granta Park, CB21 6GQ, Cambridge, UK

E-mail: mateabulic@outlook.com
Rectal drug delivery has been effective in local treatments of some diseases, as well as systemically as an alternative to oral drug delivery. Some of the advantages of rectal route of administrations include low enzymatic activity in comparison to other sections in the gastrointestinal tract (1). This is particularly useful for drugs that are prone to enzymatic degradation (1). Furthermore, upon the rectal absorption, rectally administered drugs partially bypass the liver, reducing the hepatic first-pass effect. This ensures enhanced bioavailability of the drugs (5). Moreover, the environment in empty rectum is relatively stable, constant and allows absorption of higher doses that cannot easily be formulated as the oral solid dosage forms (5).

Rectal route of administration offers a number of benefits and advantages over other routes, such as oral and parenteral, and can be helpful in situations where other routes, for safety reasons, are not recommended in certain patients. For example, rectal drug delivery is the best option for the patients that are unconscious or vomiting (1). Paediatric patients may have swallowability issues in regard to tablets and capsules and can also refu- se oral dosage forms due to poor palatability (bad taste or smell) (5). All of this can be avoided by rectal route of drug administration.

Further, parenteral drug delivery is usually not well accepted among children as it is painful at the site of the injection. It is also inconvenient in cases when a healthcare professional is needed for administration which usually needs to be done in a hospital. Rectal drug delivery allows patients to remain in home settings and administration by the help of family (6).

\section{Acceptability and use of the rectal dosage forms}

Very few studies are available on the use and acceptability of the rectal route for drug delivery in children. The acceptability is influenced by many factors such as cultural and social barriers, lack of information and knowledge, fear of discomfort, etc. (1). Evidence on acceptability and use of rectal drug delivery in children from different countries is summarised in the Table 1. 
Table 1.

Studies of acceptability and use of rectal drug delivery

\begin{tabular}{|c|c|c|c|c|c|c|}
\hline & API and purpose & Age & Country & Dosage form & Setting & Acceptability \\
\hline Study 1 (7) & $\begin{array}{l}\text { Artesunate for treating } \\
\text { Malaria }\end{array}$ & $0-18$ years & Laos & $\begin{array}{l}\text { Suppository or } \\
\text { capsule }\end{array}$ & Home & Poor \\
\hline Study 2 (8) & Paracetamol for fever & $0-6$ & Italy & Suppository & Home & Good \\
\hline Study 3 (9) & $\begin{array}{l}\text { Methohexitone for inducing } \\
\text { anaesthesia }\end{array}$ & 8 months -6 years & Norway & Enema & Hospital & Very good \\
\hline Study 4 (10) & Acetaminophen for fever & 6 months -6 years & Iran & Suppository & Hospital & Very good \\
\hline Study 5 (11) & Analgesic for pain & $<6$ years & England & Suppository & Hospital & Poor \\
\hline
\end{tabular}

First study assessed parents' acceptance of rectal dosage forms to treat Malaria in Laos, southeast Asia. Results suggested that only $9 \%$ of the participants of the questionnaire had ever used rectal dosage forms at home to treat their children. This was primarily due to the lack of information and fear of discomfort and pain. The most preferred route of drug administration was oral (42\%), followed by parenteral (39\%) and lastly rectal (4\%) (7).

Another study was conducted in Italy among paediatricians and parents whose children had fever. Interestingly, only $24.3 \%$ of paediatricians preferred rectal administration of paracetamol over oral, whereas $51 \%$ of the parents preferred rectal suppositories over oral formulations and stated to give suppositories to their children routinely. The parents believed that suppositories had faster onset of action and considered them to be more effective and easier to administer (8).

A study in Norway assessed both children's and parents' reaction to Methohexitone enemas for inducing anaesthesia prior operation. The results indicate that $82 \%$ of the children were not afraid to be anaesthetised by rectum. In addition, $100 \%$ of the parents would be happy to have the same anaesthetic technique on a subsequent occasion and did not think that the rectal route of inducing anaesthesia is 'unethical' (9).

Another study on acceptability of rectal dosage forms among parents and their children was assessed in an Iranian hospital. Results show that both patients and their parents were satisfied and approving of a rectal dosage form of acetaminophen for treating fever. However, it is believed that the opinions might change if parents themselves had to insert the suppositories to their children (10).

In one of the London's hospitals, parents participated in a questionnaire preand post-surgery in regard to acceptability of different routes of administration (oral, intravenous, intramuscular and rectal) of an analgesic for their children. The results suggest that $58 \%$ of the parents least preferred the rectal route and considered it to be the most unpleasant of all the routes. Moreover, results show that the parents' knowledge in rectal drug delivery was very limited and that education regarding the same would help change their opinions (11).

\section{Types of the rectal dosage forms}

Rectal dosage forms can be classified into solid, semi-solid and liquid dosage forms. Solid rectal dosage forms are fixed dose formulations such as suppositories, capsules, tablets, etc. The most commonly administered dosage form clinically used are suppositories (2). They contain the active compound that is either suspended or solubilised in a suitable base which upon melting or solubilisation releases the active pharmaceutical ingredient for either systemic or local action (12). The suppository base may be either lipophilic (e.g., coconut oil, cocoa butter, hard fats, etc.) or hydrophilic (e.g., glycerinated gelatine, polyethylene glycols, etc.) (1). Rectal tablets and capsules are limited marketed despite the fact that rectal capsules have been effectively used to improve absorption of drugs that undergo an extensive first pass metabolism such as propranolol and lidocaine (5).

Semi-solid rectal dosage forms comprise gels, ointments and creams in which the active compound is dispersed in lipophilic or hydrophilic base along with excipients in order to enhance the absorption (1). In semi-solid rectal dosage forms, the base selection has an impact on the drug release due to a drug's solubility in the bases (13). The most frequently used semi-solid rectal dosage form are gels. These formulations typically require an applicator filled with the formulation prior administration.

Liquid rectal dosage forms include any suspension, solution or emulsion for rectal administration and are termed as enemas (1). If the administration volume is small $(5-10 \mathrm{ml})$, these are then referred to as micro-enemas (1). These formulations contain either glycerine, oil or a low molecular weight macrogol that act as a vehicle (5). The formulations are typically administered from a disposable plastic squeeze bottle with an extended tip for rectal insertion.

\section{Reformulation of drugs for rectal delivery}

There has been an increase in research studies on reformulation of some drugs for rectal delivery. Certain drugs (intended for oral and/or parenteral use) that cannot achieve a full potential or cause severe adverse reactions may show even better efficacy and/or safety if reformulated for rectal delivery. Even some dru- 
gs that show good efficacy and safety but are orally or parenterally administered might benefit from the reformulation as majority of children find injections painful and may develop needle-phobia, whilst tablets and capsules may be challenging to swallow $(1,5,13)$.

For instance, one research study subjected all the medications from the WHO's 'Model List of Essential Medicines for Children' for an assessment based on priorly developed set of criteria. The final results suggest a possible reformulation of Azithromycin, Amodiaquine and Raltegravir for rectal delivery (6).

Despite the fact that the majority of the antibiotics is well tolerable among children in regard to efficacy and safety, children usually find the administration painful and uncomfortable. On top of that, some antibiotics may be subjected to the chemical breakdown in the enzymatic milieu of small intestine or in stomach (5). They can also be absorbed too slowly to provide satisfactory plasma levels for medicate following the oral administration (5).

Some studies have been done on rectal formulations of certain antibiotics, i.e. Amoxicillin, Azithromycin, etc. and the outcomes indicate that the rectal delivery of the same would be effective $(14,15)$. Another study's results suggest that development of new formulations of suppositories resulted in improved bioavailability and absorption of B-lactams (e.g., Benzathine benzylpenicillin) and aminoglycosides (e.g., Amikacin) (16). Tween 60, Tween 80 and various saturated straight-chain fatty acids also showed their enhancing effects on the rectal absorption of antibiotics in animals. Though, human studies are limited due to the ethical constrains (16).

Furthermore, delivery of vaccines through rectum could be of an interest as some studies obtained promising results in their research. For example, rectal immunization with Rotavirus virus-like particles along with proper adjuvants protected mice against the Rotavirus infection. This could be a promising alternative to the oral Rotavirus vaccine in infants and also against tuberculosis.
These research studies have also been tested on animals only (17).

Also, recent studies suggest a reformulation of Insulin injections for rectal delivery. Insulin injections are efficacious, safe and well tolerable among patients. However, the absorption from subcutaneous tissue varies within different insulin preparations. Therefore, some studies have been exploring a possibility of formulating an Insulin for the delivery through rectum and results have shown positive outcomes $(18,19)$.

\section{Reformulation methods and considerations}

If reformulation of these medications (and any other) was to occur, a few crucial aspects would have to be considered for successful reformulation. These include a type of dosage form the medication would be formulated as; the excipient; delivery devices if possible, etc.

Suppositories are the most common rectal dosage forms found on the market, followed by rectal gels and enemas (1, $5,13)$. Thus, some of these could be the possible dosage forms for the reformulated drugs. Ideally, the rectal dosage form would deliver a single paediatric dose (1). Dose adjustments are based on height, weight and/or body surface area. It has been relatively simpler to adjust doses for solutions and suspensions than for suppositories. This is because in many cases suppositories restrict simple dose adjustments (12). Typically, suppositories weigh $2 \mathrm{~g}$ for adults and $1 \mathrm{~g}$ for children and infants (2). Some novel stickshaped suppositories with breakability line have been made to allow division of the dosage form in two halves (5). This is particularly convenient as it allows reduction of the dose for smaller children.

Very few devices are available for suppository administration and are not specifically designed for paediatric population. However, insertion of a suppository is simple and quick (with prior washed hands) even without a device.

Excipients are a vital aspect of rectal dosage form formulation process, espe- cially for suppositories. They may be irritant, but their safety profile is well established in children. Generally, if an excipient is known to be safe for oral administration, the rectal safety should be similar as rectal epithelium has comparable abilities to absorb drugs (2). As previously stated, suppository base excipients can either be lipophilic fatty acids (e.g., cocoa butter) or hydrophilic watersoluble bases (e.g., polyethylene glycol) (1). The selection between the two ultimately depends on the physicochemical properties of the active compound. Meaning, hydrophilic drugs will show a better release profile in lipophilic bases, whereas lipophilic drugs will have a better release profile in hydrophilic bases (12). Due to the constant conditions of the rectum environment, it is possible to achieve controlled release of dosage forms. Controlled drug release is beneficial in improving pharmacokinetic profiles, mainly bioavailability of a drug (5).

Controlled drug release can be achieved using some novel rectal drug delivery systems (RDDS). Some of the RDDS involve the hollow-type suppositories, thermo-responsive liquid suppositories, micro and nanoparticles, etc. Studies on the same indicate that the RDDS minimise toxic effects of some very potent drugs (2). Further, rectal retention, spreadability and desired drug release properties are achieved by concentration modulation, leading to an optimised therapeutic outcome (20). Moreover, RDDS may outpatient paediatric treatment of some diseases at earlier stages, before they progress to severe conditions (13). The research of the safety and efficacy of the RDDS is continuous and many human clinical trials have yet to be conducted, but it is strongly believed that the use of these could yield a successful reformulation of drugs and ultimately achieve promising results.

\section{Conclusion and future work}

Rectal drug delivery has been explored as a potential alternative drug delivery system for orally and parenterally administered drugs. Some orally administered drugs can have a poor palatability, can have an extensive first pass 
metabolism (resulting in low bioavailability) or can be too irritating for the gut, whilst parenterally administered drugs can be painful and uncomfortable and usually require a healthcare professional for administration in hospital or clinical settings.

Acceptability of the rectal dosage forms was studied across the world from developed and developing countries to undeveloped world's countries. Parents' and patients' acceptability differs among the countries and the main reason behind it is the variability in knowledge and information available for the patients and their parents. It is believed that a better education on the matter would help change negative opinions. Reformulation of some available medications for rectal delivery is thought to be an interesting matter that has been widely explored. Reformulation for rectal delivery of commonly used and prescribed drugs intended for oral and/or parenteral administration could help cross the barriers and disadvantages of these routes, which would ultimately lead to a huge commercial success.

There are a few research studies that could be done and/or continued in the future. For example, recent studies' results indicate promising results and efficacy of rectal dosage forms of antibiotics. However, human studies have been limited due to ethical constrains. Therefore, future studies could focus on exploring the efficacy and safety of rectal antibiotics in humans. It could be a huge commercial success if realised as bacterial infections are the most common type of 'disease' in children.

Similarly, vaccines have shown a potential in efficacy upon rectal administration in mice. No human studies have been done on the same, but its realisation could be a focus in the future. Lastly, studies on rectal drug delivery systems (RDDS) should be continued as well as more in-depth research on their action, efficacy and safety in order to successfully establish their safety and efficacy profile.

\section{NOVČANA POTPORA/FUNDING}

Nema/None
ETIČKO ODOBRENJE/ETHICAL APPROVAL Nije potrebno/None

\section{SUKOB INTERESA/CONFLICT OF INTEREST}

Autori su popunili the Unified Competing Interest form na www.icmje.org/coi_disclosure.pdf (dostupno na zahtjev) obrazac i izjavljuju: nemaju potporu niti jedne organizacije za objavljeni rad; nemaju financijsku potporu niti jedne organizacije koja bi mogla imati interes za objavu ovog rada u posljednje 3 godine; nemaju drugih veza ili aktivnosti koje bi mogle utjecati na objavljeni rad./ All authors have completed the Unified Competing Interest form at www.icmje.org/coi_disclosure. $p d f$ (available on request from the corresponding author) and declare: no support from any organization for the submitted work; no financial relationships with any organizations that might have an interest in the submitted work in the previous 3 years; no other relationships or activities that could appear to have influenced the submitted work.

\section{LITERATURE}

1. Hua S. Physiological and Pharmaceutical Considerations for Rectal Drug Formulations. Front Pharmacol. 2019; 10: 1196. doi: 10.3389/ fphar.2019.01196

2. Jannin V, Lemagnen G, Gueroult P, Larrouture D, Tuleu C. Rectal route in the 21 st Century to treat children. Advanced Drug Delivery Reviews. 2014; 73: 34-49. doi: 10.1016/j. addr.2014.05.012

3. Dimitrov G, Gottrand F. Does gastric atrophy exist in children? World J Gastroenterol. 2006; 12: 6274-9. doi: 10.3748/wjg.v12.i39.6274

4. Fernandez E, Perez R, Hernandez A, Tejada P, Arteta M, Ramos J. Factors and Mechanisms for Pharmacokinetic Differences between Pediatric Population and Adults. Pharmaceutics. 2011; 3: 53-72. doi: 10.3390/pharmaceutics 3010053

5. Baviskar P, Bedse A, Sadique S, Kunde V, Jaiswal S. Drug Delivery on Rectal Absorption: Suppositories. Int J Pharm Sci Rev Res. 2013; 21: 70-6.

6. Bulic M. Reformulation Prospects of Drug Candidates from WHO's 'Model List of Essential Medicines for Children' for Rectal Drug Delivery (dissertation). London: University College London; 2020.

7. Inthavilay S, Franchard T, Meimei Y, Ashley E, Barennes H. Knowledge and acceptability of the rectal treatment route in Laos and its application for pre-referral emergency malaria treatment. Malaria Journal. 2010; 9: 342. doi: $10.1186 / 1475-2875-9-342$

8. Chiappini E, Parretti A, Becherucci P, Pierattelli M, Bonsignori F, Galli L et al. Parental and medical knowledge and management of fever in Italian pre-school children. BMC Pediatrics. 2012; 12: 97. doi: 10.1186/1471-243112-97
9. Quaynor H, Corbey M, Bjorkman S. Rectal induction of anaesthesia in children with methohexitone. Br. J. Aaesth. 1985; 57: 73-577. doi: 10.1093/bja/57.6.573

10. Karbasi S A, Modares-Mosadegh M, Golestan M. Comparison of antipyretic effectiveness of equal doses of rectal and oral acetaminophen in children. J. Pediatr. (Rio J.) 2010; 86: 228-32. doi: 10.2223/JPED.1992

11. Seth N, Llewellyn N, Howard R. Parental opinions regarding the route of administration of analgesic medication in children. Pediatric Anesthesia. 2000; 10: 537-44. doi: 10.1046/j.1460-9592.2000.00564.x

12. Batchelor H, Marriott J. Formulations for children: problems and solutions. British Journal of Clinical Pharmacology. 2015; 79: 405-18. doi: $10.1111 /$ bcp. 12268

13. Purohit T, Hanning S, Wu Z. Advances in rectal drug delivery systems. Pharmaceutical Development and Technology. 2018; 23: 94252. doi: 10.1080/10837450.2018.1484766

14. Hanning S, Matiz S, Krasser K, Orlu M, Dodoo $\mathrm{C}$, Gaisford $\mathrm{S}$ et al. Characterisation of rectal amoxicillin (RAMOX) for the treatment of pneumonia in children. Drug Delivery and Translational Research. 2020; 11: 944-55. doi:10.1007/s13346-020-00804-6

15. Kauss T, Gaudin K, Gaubert A, Tagliaferri S, Fawaz F, Fabre J et al. Screening paediatric rectal forms of azithromycin as an alternative to oral or injectable treatment. International Journal of Pharmaceutics. 2012; 436: 624-30. doi: 10.1016/j.ijpharm.2012.07.030.

16. Bergogne-Berezin E, Bryskier A. The suppository form of antibiotic administration: pharmacokinetics and clinical application. Journal of Antimicrobial Chemotherapy, 1999; 43: 17785. doi: 10.1093/jac/43.2.177

17. Parez N, Fourgeux C, Mohamed A, Dubuquoy C, Pillot M, Dehee A, Charpilienne A et al. Rectal Immunization with Rotavirus VirusLike Particles Induces Systemic and Mucosal Humoral Immune Responses and Protects Mice against Rotavirus Infection. Journal of Virology, 2006; 80: 1752-61. doi: 10.1128/ JVI.80.4.1752-1761.2006

18. Hosny EA. Rectal delivery of Insulin: The Promising Route. Ecronicon. 2019 Sept 30.

19. Yamasaki Y, Shichiri M, Kawamori R, Kikuchi M., Yagi T, Ara S et al. The Effectiveness of Rectal Administration of Insulin Suppository on Normal and Diabetic Subjects. Diabetes Care. 1981; 4: 454-8. doi: 10.2337/diacare.4.4.454

20. Ramadan AA, Elbakry AM, Esmaeil AH, Khaleel SA. Pharmaceutical and pharmacokinetic evaluation of novel rectal mucoadhesive hydrogels containing tolmetin sodium. J Pharm Investig. 2018; 48: 673-83. doi: 10.1007/ s40005-017-0365-1 
Sažetak

\section{REKTALNA PRIMJENA LIJEKOVA U PEDIJATRIJSKOJ POPULACIJI}

\section{Matea Bulić, Catherine Tuleu}

Rektalna primjena lijekova nije popularna. Unatoč tome je pogotovo značajna u pedijatriji, u djece predškolske dobi, jer može prevladati probleme povezane s oralnim i parenteralnim putevima primjene lijekova. Provedeno je nekoliko studija o primjeni $i$ prihvatljivosti tradicionalnih načina upotrebe lijeka (npr. čepići, klistir i gelovi) u različitim dijelovima svijeta. Studije ukazuju da je neprihvaćanje povezano sa slabim poznavanjem, manjkom dostupnih informacija i razumijevanjem rektalne primjene lijekova. Neki lijekovi namijenjeni za oralnu i/ili parenteralnu upotrebu zbog različitih razloga ne postižu svoj potpuni učinak takvim načinom primjene. Preformulacija takvih lijekova u oblik za rektalnu primjenu je istraživana na University College London. Rezultati su pokazali da su najbolji kandidati ispitivanih lijekova za preformulaciju Azithromycin, Amodiaquine $i$ Raltegravir. U posljednje vrijeme nema inovacija o rektalnoj primjeni lijekova. Međutim publiciraju se radovi o prihvatljivost $i$ uporabi rektalnih lijekova te mogućnostima preformulacije različitih preparata da bi se podigla svijest o takvom korisnom načinu liječenja u djece.

Ključne riječi: DJECA, REKTALNA PRIMJENA LIJEKOVA, VRSTE REKTALNIH LIJEKOVA, PREFORMULACIJA

Primljeno/Received: 12. 10. 2021.

Prihvaćeno/Accepted: 8. 11. 2021. 